Original Article

\title{
Efficacy of Carperitide in Hemodialysis Patients Undergoing Cardiac Surgery
}

\author{
Akira Sezai, MD, PhD, Shunji Osaka, MD, PhD, Hiroko Yaoita, MD, PhD, \\ Yusuke Ishii, MD, PhD, Munehito Arimoto, MD, Hiroaki Hata, MD, PhD, \\ and Motomi Shiono, MD, $\mathrm{PhD}$
}

\begin{abstract}
Purpose: Recently, performance of cardiac surgery in hemodialysis patients has increased, but the mortality rate is high.

Methods: We retrospectively examined the early and long-term outcomes in 128 dialysis patients who underwent cardiac surgery with or without carperitide infusion and were followed for 2 years. Sixty-three patients received carperitide infusion during surgery and 65 patients did not. Results: The hospital mortality rate was $1.6 \%$ in the carperitide group and $12.3 \%$ in the non-carperitide group, being significantly lower in the carperitide group. The 2-year actuarial survival rate was $\mathbf{9 0 . 5 \%} \pm \mathbf{3 . 7 \%}$ in the carperitide group, and $\mathbf{7 6 . 9 \%} \pm \mathbf{5 . 2 \%}$ in the non-carperitide group, while the major adverse cardiovascular and cerebrovascular events (MACCE)-free rate at 2 years postoperatively was $90.5 \% \pm 3.7 \%$ in the carperitide group and $67.7 \% \pm 5.8 \%$ in the non-carperitide group.

Conclusions: These findings suggest that carperitide improves the early postoperative outcome in dialysis patients undergoing cardiac surgery, as has already been demonstrated in non-dialysis patients. An early postoperative cardioprotective effect of carperitide and improvement of renal function in oliguric patients might have contributed to this outcome. However, this was a retrospective study, so a prospective investigation is required to demonstrate the mechanisms involved. In addition, further evaluation of the long-term results would be desirable.
\end{abstract}

Keywords: dialysis, chronic kidney disease, coronary artery bypass grafting, cardiac surgery

\section{Introduction}

Recently, performance of cardiac surgery in hemodialysis patients has increased, but the early mortality rate is still high. ${ }^{1-11)}$ In addition, many patients develop major cardiac and cerebrovascular events or infections after discharge and the long-term results are not satisfactory.

The Department of Cardiovascular Surgery, Nihon University School of Medicine, Tokyo, Japan

Received: July 27, 2015; Accepted: March 15, 2016

Corresponding author: Akira Sezai, MD, PhD. The Department of Cardiovascular Surgery, Nihon University School of Medicine, 30-1 Oyaguchi-Kamimachi, Itabashi-Ku, Tokyo 173-8610, Japan Email: asezai.med@gmail.com

(C)2016 The Editorial Committee of Annals of Thoracic and Cardiovascular Surgery. All rights reserved.
Yeo et al. reported that the operative mortality of coronary artery bypass grafting $(\mathrm{CABG})$ increased significantly with each stage of chronic kidney disease (CKD), and patients in stage 5 (estimated glomerular filtration rate (eGFR) $<15 \mathrm{ml} / \mathrm{min} / 1.73 \mathrm{~m}^{2}$ or dialysis) had a far higher operative mortality than patients in stage 4 or lower. ${ }^{12)}$ Since both the early and long-term results of cardiac surgery are unsatisfactory in patients on dialysis or patients with severe $\mathrm{CKD}$, there is an urgent need to establish a new treatment strategy. There have been many reports comparing offpump with on-pump CABG in hemodialysis patients, as well as reports about different intraoperative filtration methods. With regard to CABG, numerous studies have focused on graft selection and comparison of CABG with percutaneous coronary intervention. However, there have been few investigations of perioperative medications. We have 
Table 1 Comparison of clinical characteristics

\begin{tabular}{|c|c|c|c|}
\hline & Carperitide group & Non-carperitide group & $\mathrm{p}$ value \\
\hline Number & 63 & 65 & \\
\hline $\begin{array}{l}\text { Age (years) } \\
>75 \text { years }\end{array}$ & $\begin{array}{c}65.4 \pm 9.4 \\
11(17 \%)\end{array}$ & $\begin{array}{l}67.2 \pm 8.2 \\
14(22 \%)\end{array}$ & $\begin{array}{l}0.254 \\
0.561\end{array}$ \\
\hline $\begin{array}{l}\text { Gender (male: female) } \\
\text { Body surface area }\left(\mathrm{m}^{2}\right)\end{array}$ & $\begin{array}{c}49: 14 \\
1.60 \pm 0.16\end{array}$ & $\begin{array}{c}44: 21 \\
1.54 \pm 0.16\end{array}$ & $\begin{array}{l}0.201 \\
0.06\end{array}$ \\
\hline $\begin{array}{l}\text { Diagnosis } \\
\text { IHD } \\
\text { Valvular disease } \\
\text { Aortic disease } \\
\text { IHD + valve } \\
\text { Valve + aorta }\end{array}$ & $\begin{array}{r}43 \\
4 \\
0 \\
12 \\
1\end{array}$ & $\begin{array}{r}41 \\
15 \\
3 \\
6 \\
0\end{array}$ & 0.671 \\
\hline $\begin{array}{l}\text { Cause of CKD } \\
\text { Diabetic nephropathy } \\
\text { Chronic glomerulonephritis } \\
\text { Nephrosclerosis } \\
\text { Others }\end{array}$ & $\begin{array}{r}47 \\
11 \\
2 \\
3\end{array}$ & $\begin{array}{r}41 \\
21 \\
2 \\
1\end{array}$ & 0.186 \\
\hline $\begin{array}{l}\text { Anuria } \\
\text { Oliguria } \\
\text { Emergency or urgent } \\
\text { Re-operation }\end{array}$ & $\begin{array}{c}39 \\
24 \\
12(19 \%) \\
1(2 \%)\end{array}$ & $\begin{array}{c}50 \\
15 \\
19(29 \%) \\
2(3 \%)\end{array}$ & $\begin{array}{l}0.065 \\
0.179 \\
0.578\end{array}$ \\
\hline $\begin{array}{l}\text { Risk factors } \\
\text { Diabetes mellitus } \\
\text { Hypertension } \\
\text { Dyslipidemia } \\
\text { Obesity } \\
\text { Smoking } \\
\text { LV dysfunction } \\
\text { COPD } \\
\text { Cerebrovascular disease } \\
\text { PAD }\end{array}$ & $\begin{array}{l}42(67 \%) \\
55(87 \%) \\
21(33 \%) \\
18(29 \%) \\
23(37 \%) \\
20(32 \%) \\
3(5 \%) \\
2(3 \%) \\
19(30 \%)\end{array}$ & $\begin{aligned} & 40(62 \%) \\
& 52(80 \%) \\
& 17(26 \%) \\
& 8(12 \%) \\
& 22(34 \%) \\
& 19(29 \%) \\
& 0(0 \%) \\
& 5(8 \%) \\
& 16(25 \%)\end{aligned}$ & $\begin{array}{l}0.545 \\
0.265 \\
0.374 \\
0.022 \\
0.752 \\
0.757 \\
0.075 \\
0.261 \\
0.482\end{array}$ \\
\hline $\begin{array}{l}\text { Previous PCI } \\
\text { Ejection fraction (\%) } \\
\text { Duration of HD (years) }\end{array}$ & $\begin{array}{l}11(17 \%) \\
51.6 \pm 14.7 \\
6.23 \pm 3.86\end{array}$ & $\begin{array}{l}13(20 \%) \\
51.5 \pm 14.3 \\
6.97 \pm 4.73\end{array}$ & $\begin{array}{l}0.713 \\
0.891 \\
0.251\end{array}$ \\
\hline
\end{tabular}

IHD: ischemic heart disease; CKD: chronic kidney disease; LV: left ventricular; COPD: chronic obstructive pulmonary disease; PAD: peripheral artery disease; PCI: percutaneous coronary intervention; HD: hemodialysis

previously performed several prospective trials to investigate the effects of carperitide in non-dialysis patients undergoing cardiac surgery, and we have reported that this drug has a cardioprotective effect, a renoprotective effect, counteracts the adverse influence of cardiopulmonary bypass, inhibits the renin-angiotensin-aldosterone system (RAAS), inhibits left ventricular remodeling, and has an antiarrhythmic effect. ${ }^{13-19)}$ With regard to the renoprotective effect of carperitide, we have found both acute and longterm avoidance of dialysis, RAAS inhibition, and a potent natriuretic action in non-dialysis patients with CKD. ${ }^{16,17)}$

Accordingly, we performed the present retrospective investigation to assess the effectiveness of carperitide in dialysis patients undergoing cardiac surgery.

\section{Patients and Methods}

One hundred and twenty-eight hemodialysis patients underwent cardiac surgery at Nihon University Itabashi Hospital between April 2001 and March 2013, including 63 patients who received carperitide infusion during surgery (carperitide group) and 65 patients who did not receive carperitide (non-carperitide group). All of the patients had chronic kidney disease and no patients receiving acute or sub-acute hemodialysis were included in this study.

A 2-year retrospective investigation of postoperative outcomes was performed in this cohort with a $100 \%$ follow-up rate. The details of the study were explained to each patient and informed consent was obtained. 
Infusion of carperitide was initiated at $0.05 \mathrm{ag} / \mathrm{min} / \mathrm{kg}$ at the start of cardiopulmonary bypass. Once postoperative oral medication was commenced, the infusion rate was reduced to $0.02 \mu \mathrm{g} / \mathrm{min} / \mathrm{kg}$. The infusion rate was further reduced to $0.01 \mu \mathrm{g} / \mathrm{min} / \mathrm{kg} 12 \mathrm{~h}$ later, and carperitide was discontinued after another $12 \mathrm{~h}$.

As shown in Table 1, there were no significant differences of background factors between the carperitide and non-carperitide groups. In patients having elective surgery, dialysis was performed on the day before the operation. Intraoperative hemofiltration was performed in all patients and hemodialysis was resumed 1 or 2 days after surgery based on factors such as the severity of pulmonary congestion on chest X-ray films and the serum potassium level.

The following preoperative factors were examined for an influence on outcomes: age $\geq 75$ years, gender, shock, emergency surgery, preoperative use of an intra-aortic balloon pump (IABP), previous percutaneous coronary intervention, re-operation, hypertension, diabetes mellitus, dyslipidemia, obesity, smoking, peripheral artery disease (PAD), chronic obstructive pulmonary disease (COPD), anuria, ejection fraction $(\mathrm{EF})<35 \%$, and cerebrovascular disease. The following intraoperative and postoperative factors were also examined: aortic cross-clamping time (ACCT) $\geq 90 \mathrm{~min}$, cardiopulmonary bypass time (CPBT) $\geq 180 \mathrm{~min}$, use of carperitide, and postoperative atrial fibrillation (POAF). Furthermore, occurrence of early death and major adverse cardiovascular and cerebrovascular events (MACCE) was investigated. MACCE were defined as all cause death, postoperative cardiac failure, myocardial infarction, repeat revascularization, hospitalization for heart failure, and cerebrovascular accidents.

Logistic regression analysis was employed to assess the relations of preoperative, intraoperative, and postoperative factors to early death and MACCE.

\section{Statistical analysis}

Results are expressed as the mean \pm standard deviations (SD). Univariate logistical regression analysis of preoperative, intraoperative, and postoperative factors was performed, after which the variables showing significance were subjected to multivariate analysis. The overall mortality rate, cardiovascular mortality rate, and postoperative cardiovascular event-free rate were determined by the Kaplan-Meier method. Student's t-test and the chi-square test were used for other statistical analyses. A probability of less than $0.05(\mathrm{p}<0.05)$ was considered to indicate statistical significance.

\section{Results}

The preoperative background factors and the intraoperative and postoperative factors of the 128 patients are summarized in Table 2.

\section{Operative mortality (Table 2)}

The hospital mortality rate was $1.6 \%(n=1)$ in the carperitide group and $12.3 \%(n=8)$ in the non-carperitide group, showing a significant difference between the two groups $(\mathrm{p}=0.0018)$.

The cause of death was ventricular arrhythmia in one patient from the carperitide group, while it was low output syndrome in three patients, ventricular arrhythmia in two patients, and mediastinitis, postoperative bleeding, and cerebral infarction in one patient each from the non-carperitide group.

Three patients from the non-carperitide group died after undergoing single surgical procedures (mortality rate of $2.9 \%$ ), including two deaths after CABG and one after aortic valve replacement (AVR). There were six deaths in the non-carperitide group after combined surgery (mortality rate of $23.1 \%$ ), including four deaths after CABG + AVR, 1 death after $\mathrm{CABG}+\mathrm{AVR}+$ mitral annuloplasty (MAP), and one death after CABG + double valve replacement (DVR). In the carperitide group, two oliguric patients were weaned from dialysis after surgery. Excluding three patients with preoperative atrial fibrillation (carperitide group: 2, non-carperitide group: 1), POAF occurred in nine patients from the carperitide group (14.8\%) and 34 patients $(53.1 \%)$ from the non-carperitide group. There was a significantly higher frequency of POAF in the non-carperitide groups $(\mathrm{p}<0.0001)$.

\section{Late results and MACCE (Table 2)}

Within 2 years after discharge from hospital, five patients from the carperitide group and seven patients from the non-carperitide group died, while MACCE occurred in six patients from the carperitide group and 21 patients from the non-carperitide group $(\mathrm{p}=0.0009)$. The 2-year mortality rate and 2-year MACCE rate were both significantly lower in the carperitide group $(\mathrm{p}=0.055$ for mortality and $p=0.002$ for MACCE). The five deaths in the carperitide group were due to heart failure and sudden death in two patients each and unstable angina in one patient. The seven deaths in the non-carperitide group were due to heart failure in three patients and gastrointestinal bleeding in two patients, followed by sepsis and sudden death in one patient each. The deaths of all six patients 
Table 2 Postoperative results

\begin{tabular}{|c|c|c|c|}
\hline & Carperitide group & Non-Carperitide group & $\mathrm{p}$ value \\
\hline Number & 63 & 65 & \\
\hline Hospital death & $1(1.6 \%)$ & $8(12.3 \%)$ & 0.018 \\
\hline Mortality within 2 years after surgery & 6 & 15 & 0.055 \\
\hline MACCE within 2 years after surgery & 6 & 21 & 0.002 \\
\hline \multicolumn{4}{|l|}{ Procedure } \\
\hline CABG (on pump: OPCAB) & $44(42: 2)$ & $41(40: 1)$ & \\
\hline AVR & 3 & 10 & \\
\hline MVR & 0 & 1 & \\
\hline Asc-Ao replacement & 0 & 3 & \\
\hline $\mathrm{CABG}+$ valve surgery & 12 & 6 & \\
\hline CABG + Dor & 1 & 0 & \\
\hline AVR + Maze & 1 & 0 & \\
\hline $\mathrm{AVR}+\mathrm{MVR}$ & 0 & 2 & \\
\hline $\mathrm{AVR}+\mathrm{MVR}+\mathrm{Maze}$ & 0 & 1 & \\
\hline $\mathrm{AVR}+\mathrm{MVR}+\mathrm{TAP}$ & 0 & 1 & \\
\hline AVR + Asc-Ao replacement & 1 & 0 & \\
\hline AVR + MVR + Asc-Ao replacement & 1 & 0 & \\
\hline Numbers of distal anastomoses & $2.68 \pm 0.85$ & $2.42 \pm 0.99$ & 0.004 \\
\hline $\operatorname{ACCT}(\min )$ & $75.2 \pm 63.3$ & $82.7 \pm 56.3$ & 0.314 \\
\hline $\mathrm{ACCT}>90 \mathrm{~min}$ & $15(24 \%)$ & $23(35 \%)$ & 0.152 \\
\hline $\mathrm{CPBT}(\min )$ & $141.3 \pm 66.3$ & $146.6 \pm 64.3$ & 0.530 \\
\hline $\mathrm{CPBT}>180 \mathrm{~min}$ & $9(14 \%)$ & $18(28 \%)$ & 0.063 \\
\hline Dopamine use & $47(75 \%)$ & $50(79 \%)$ & 0.759 \\
\hline Dobutamine use & $31(49 \%)$ & $34(52 \%)$ & 0.726 \\
\hline Epinephrine use & $4(6 \%)$ & $12(18 \%)$ & 0.038 \\
\hline Norepinephrine use & $9(14 \%)$ & $21(32 \%)$ & 0.016 \\
\hline Landiolol hydrochloride & $18(29 \%)$ & $20(31 \%)$ & 0.786 \\
\hline Preoperative AF & $2(3 \%)$ & $1(2 \%)$ & 0.541 \\
\hline POAF & $9(14.8 \%)$ & $34(53.1 \%)$ & $<0.0001$ \\
\hline Weaning from respirator (days) & $1.03 \pm 1.15$ & $2.04 \pm 3.20$ & 0.022 \\
\hline Resuming dialysis (days) & $1.71 \pm 0.78$ & $1.27 \pm 0.57$ & $<0.0001$ \\
\hline \multicolumn{4}{|l|}{ Urine volume (Oliguria case) } \\
\hline POD 1 & $312.8 \pm 721.0$ & $29.3 \pm 89.0$ & 0.002 \\
\hline POD 2 & $346.0 \pm 808.8$ & $38.8 \pm 123.1$ & 0.003 \\
\hline POD 3 & $356.1 \pm 852.3$ & $35.8 \pm 98.6$ & 0.003 \\
\hline Disturbance of consciousness & $3(5 \%)$ & $6(9 \%)$ & 0.323 \\
\hline Hospital stay (days) & $15.8 \pm 10.0$ & $23.9 \pm 24.1$ & 0.015 \\
\hline
\end{tabular}

MACCE: major adverse cardiac and cerebrovascular events; CABG: coronary artery bypass grafting; OPCAB: off pump coronary artery bypass; AVR: aortic valve replacement; MVR: mitral valve replacement; Asc-Ao: ascending aorta; TAP: tricuspid valve annuloplasty; ACCT: aortic cross-clamping tine; CPBT: cardiopulmonary bypass time; AF: atrial fibrillation; POAF: postoperative atrial fibrillation; POD: postoperative day

from the carperitide group were classified as MACCE. In the non-carperitide group, the deaths of 15 patients were classified as MACCE, followed by death due to low output syndrome, perioperative myocardial infarction, heart failure, ventricular arrhythmia, cerebral infarction, and cerebral haemorrhage in one patient each.

In the carperitide group, the survival rate at 6 months postoperatively was $98.4 \% \pm 1.6 \%$, the 1 -year survival rate was $95.2 \% \pm 2.7 \%$, and the 2-year survival rate was
$90.5 \% \pm 3.7 \%$, while the 6-month survival rate was $81.5 \%$ $\pm 4.8 \%$, the 1-year survival rate was $78.5 \% \pm 5.1 \%$, and the 2-year survival rate was $76.9 \% \pm 5.2 \%$ in the non-carperitide group. These survival rates were all significantly higher in the carperitide group $(\mathrm{p}=0.031)$ (Fig. 1). In the carperitide group, the MACCE-free rate was $96.8 \% \pm 2.2 \%$ at 6 months postoperatively, $95.2 \% \pm 2.7 \%$ at 1 year, and $90.5 \% \pm 3.7 \%$ at 2 years, while the MACCE-free rate was $72.3 \% \pm 5.5 \%$ at 6 months, $69.2 \% \pm 5.7 \%$ at 1 year, and $67.7 \% \pm 5.8 \%$ at 

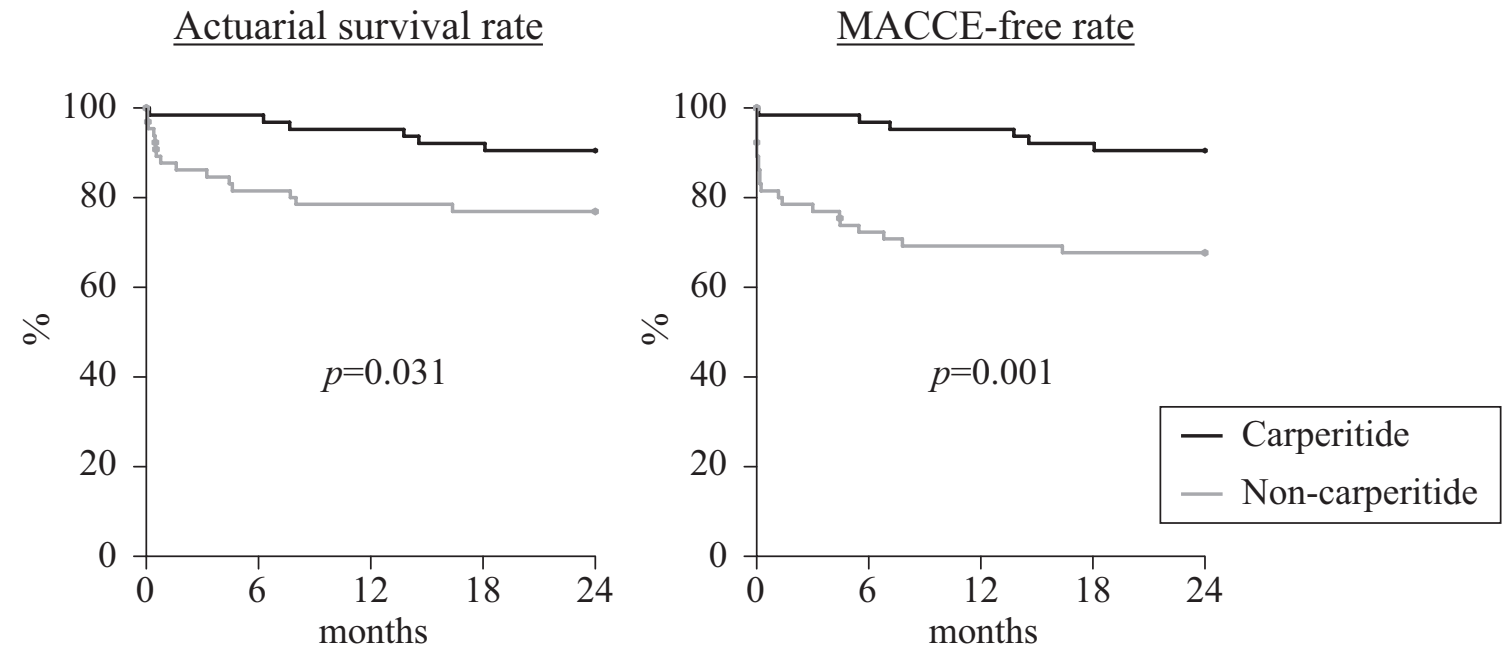

Fig. 1 Overall survival rate and postoperative MACCE-free rate. MACCE: major adverse cardiovascular and cerebrovascular events

Table 3 Preoperative, intraoperative and postoperative factors and early death

\begin{tabular}{|c|c|c|c|c|}
\hline & \multicolumn{2}{|c|}{ Univariate } & \multicolumn{2}{|c|}{ Multivariate } \\
\hline & Odds ratio $(95 \% \mathrm{CI})$ & $\mathrm{p}$ value & Odds ratio $(95 \% \mathrm{CI})$ & $\mathrm{p}$ value \\
\hline \multicolumn{5}{|l|}{ Preoperative factors } \\
\hline Age $\geq 75$ years & $11.1(2.54-49.5)$ & 0.001 & $13.4(2.44-73.5)$ & 0.003 \\
\hline Gender (male) & $0.16(0.04-0.69)$ & 0.014 & $0.25(0.05-1.29)$ & 0.098 \\
\hline Shock & $4.79(0.45-51.5)$ & 0.200 & & \\
\hline Emergency & $0.88(0.17-4.46)$ & 0.874 & & \\
\hline Preoperative IABP use & $2.31(0.43-12.3)$ & 0.328 & & \\
\hline Previous PCI & $0.55(0.07-4.59)$ & 0.577 & & \\
\hline Re-operation & $4.79(0.45-51.5)$ & 0.196 & & \\
\hline Hypertension & $1.63(0.19-13.8)$ & 0.653 & & \\
\hline Diabetes mellitus & $2.01(0.40-10.1)$ & 0.398 & & \\
\hline Dyslipidaemia & $1.19(0.28-5.01)$ & 0.817 & & \\
\hline Obesity & $0.47(0.06-3.90)$ & 0.480 & & \\
\hline Smoking & $0.52(0.10-2.60)$ & 0.424 & & \\
\hline PAD & $1.40(0.33-5.96)$ & 0.646 & & \\
\hline COPD & - & 0.980 & & \\
\hline Anuria & $3.80(0.46-31.5)$ & 0.216 & & \\
\hline Cardiac dysfunction $(\mathrm{EF}<35 \%)$ & $1.90(0.48-7.49)$ & 0.361 & & \\
\hline Cerebrovascular disease & - & 0.979 & & \\
\hline \multicolumn{5}{|l|}{$\begin{array}{l}\text { Intraoperative and } \\
\text { postoperative factors }\end{array}$} \\
\hline $\mathrm{ACCT} \geq 90 \mathrm{~min}$ & $1.19(0.28-5.01)$ & 0.817 & & \\
\hline $\mathrm{CPBT} \geq 180 \mathrm{~min}$ & $3.30(0.82-13.3)$ & 0.092 & & \\
\hline Carperitide & $0.11(0.01-0.93)$ & 0.043 & $0.16(0.12-1.62)$ & 0.120 \\
\hline POAF & $7.37(1.46-37.2)$ & 0.016 & $4.56(0.71-29.5)$ & 0.110 \\
\hline
\end{tabular}

95\% CI: 95\% confidence level; IABP: intra-aortic balloon pump; PCI: percutaneous coronary intervention; PAD: peripheral artery disease; COPD: chronic obstructive pulmonary disease; EF; ejection fraction;

ACCT: aortic cross-clamping time; CPBT: cardiopulmonary bypass time; POAF: postoperative atrial fibrillation 
Table 4 Preoperative, intraoperative and postoperative factors and MACCE (within 2 years)

\begin{tabular}{|c|c|c|c|c|}
\hline & \multicolumn{2}{|l|}{ Univariate } & \multicolumn{2}{|c|}{ Multivariate } \\
\hline & Odds ratio $(95 \% \mathrm{CI})$ & $\mathrm{p}$ value & Odds ratio $(95 \% \mathrm{CI})$ & $\mathrm{p}$ value \\
\hline \multicolumn{5}{|l|}{ Preoperative factors } \\
\hline Age $\geq 75$ years & $2.69(1.01-7.69)$ & 0.044 & $2.01(0.62-6.52)$ & 0.244 \\
\hline Gender (male) & $0.18(0.07-0.49)$ & 0.001 & $0.26(0.09-0.77)$ & 0.015 \\
\hline Shock & $5.89(0.78-44.5)$ & 0.086 & & \\
\hline Emergent & $1.42(0.50-4.09)$ & 0.513 & & \\
\hline Preoperative IABP use & $2.21(0.63-7.78)$ & 0.219 & & \\
\hline Previous PCI & $0.43(0.09-2.01)$ & 0.287 & & \\
\hline Re-operation & $1.84(0.18-18.7)$ & 0.605 & & \\
\hline Hypertension & $0.47(0.16-1.39)$ & 0.173 & & \\
\hline Diabetes mellitus & $1.05(0.39-2.85)$ & 0.924 & & \\
\hline Dyslipidaemia & $0.76(0.25-2.26)$ & 0.618 & & \\
\hline Obesity & $1.38(0.45-4.23)$ & 0.572 & & \\
\hline Smoking & $0.28(0.08-1.00)$ & 0.051 & & \\
\hline PAD & $0.87(0.29-2.59)$ & 0.798 & & \\
\hline COPD & - & 0.978 & & \\
\hline Anuria & $10.3(1.33-80.1)$ & 0.026 & $5.27(0.63-44.0)$ & 0.125 \\
\hline Cardiac dysfunction (EF <35\%) & $0.97(0.34-2.76)$ & 0.961 & & \\
\hline Cerebrovascular disease & - & 0.978 & & \\
\hline \multicolumn{5}{|l|}{$\begin{array}{l}\text { Intraoperative and } \\
\text { postoperative factors }\end{array}$} \\
\hline $\mathrm{ACCT} \geq 90 \mathrm{~min}$ & $0.76(0.25-2.26)$ & 0.618 & & \\
\hline $\mathrm{CPBT} \geq 180 \mathrm{~min}$ & $1.76(0.60-5.11)$ & 0.302 & & \\
\hline Carperitide & $0.38(0.14-0.91)$ & 0.017 & $0.19(0.05-0.75)$ & 0.038 \\
\hline POAF & $4.41(1.61-12.1)$ & 0.004 & $3.61(1.13-11.6)$ & 0.031 \\
\hline
\end{tabular}

MACCE: major adverse cardiovascular and cerebrovascular events; 95\% CI: 95\% confidence level; IABP: intra-aortic balloon pump; PCI: percutaneous coronary intervention; PAD: peripheral artery disease; COPD: chronic obstructive pulmonary disease; EF; ejection fraction; ACCT: aortic cross-clamping time; CPBT: cardiopulmonary bypass time; POAF: postoperative atrial fibrillation

2 years in the non-carperitide group. The MACCE-free rates were also significantly higher in the carperitide group $(\mathrm{p}=0.001)$ (Fig. 1).

\section{Risk factors for early death (Table 3)}

Univariate analysis demonstrated that an age $\geq 75$ years $(p=0.001)$, female sex $(p=0.014)$, non-use of carperitide $(p=0.043)$, and POAF $(p=0.016)$ were risk factors for all cause death, while multivariate analysis only identified an age $\geq 75$ years $(\mathrm{p}=0.003)$ as a risk factor.

\section{Risk factors for MACCE (Table 4)}

Univariate analysis indicated that an age $\geq 75$ years $(\mathrm{p}=$ $0.044)$, female sex $(p=0.001)$, anuria $(p=0.026)$, non-use of carperitide $(\mathrm{p}=0.017)$, and POAF $(\mathrm{p}=0.004)$ were risk factors for MACCE. Multivariate analysis confirmed that female $\operatorname{sex}(p=0.0015)$, non-use of carperitide $(p=0.038)$, and POAF $(\mathrm{p}=0.031)$ were risk factors.

\section{Discussion}

The results of this study suggested that infusion of carperitide during cardiac surgery is effective for dialysis patients, as has previously been demonstrated in non-dialysis patients. There have been numerous reports about the renoprotective effects of carperitide. Valsson et al. administered carperitide for $30 \mathrm{~min}$ to patients with acute renal failure and cardiac failure after cardiac surgery, and reported that the urine output, glomerular filtration rate, and renal blood flow increased by $62 \%, 43 \%$, and $38 \%$, respectively, while renal vascular resistance decreased by $30 \%{ }^{20)}$ They also performed a larger study which revealed that the need for dialysis was decreased by carperitide and dialysis-free survival was improved. ${ }^{21)}$ However, even outside the cardiac surgery field, no studies on the efficacy of carperitide in hemodialysis patients have been reported. In dialysis patients, the renoprotective effect of carperitide 
has no value. However, the present study demonstrated that carperitide was particularly effective for oliguric patients who showed an increase of perioperative urine volume that facilitated postoperative fluid management. There were slightly more oliguric patients in the carperitide group, although the difference from the non-carperitide group was not significant, but it is possible that this led to better early outcomes in the carperitide group. In the future, a larger patient population should be investigated to allow stratified analysis for comparison between oliguric and anuric patients.

Dialysis is usually resumed on the day after surgery. Dialysis was resumed on or after postoperative day 2 in 35 patients from the carperitide group (56\%: postoperative day 2 in 26 patients and postoperative day 3 in 9), while it was resumed on or after postoperative day 2 in 21 patients from the non-carperitide group (32\%: postoperative day 2 in 20 patients and postoperative day 3 in 1). The percentage of patients with late resumption of dialysis was significantly higher in the carperitide group $(\mathrm{p}=$ 0.008 ) and there was also a significant difference in the date of resumption $(\mathrm{p}<0.0001)$. Thus, carperitide may be beneficial for perioperative management of dialysis patients in relation to the timing of resumption of dialysis. In fact, two patients in the carperitide group could be weaned from dialysis after surgery. Both patients had commenced dialysis within 3 months before surgery and had preoperative serum creatinine levels of $6-8 \mathrm{mg} / \mathrm{dL}$ with a urine output of approximately $300 \mathrm{~mL} /$ day, but their early postoperative urine output increased to 2,000 $\mathrm{mL} /$ day or more along with improvement of serum creatinine to $2 \mathrm{mg} / \mathrm{dL}$. While no studies of carperitide have demonstrated a regenerative effect on the kidneys, this drug may a positive impact on the residual normal kidney cells. Since improvement of the ankle pressure index and leg/foot ulcers has been reported after administration of carperitide for 2 weeks to patients with peripheral arterial disease and diabetes, ${ }^{22}$ ) this drug may have the potential to promote vascular regeneration and improve endothelial dysfunction at the capillary level, but further investigation of this issue is required.

Although carperitide may not be able to benefit the kidneys in dialysis patients, it improved early and late postoperative results by preventing the occurrence of MACCE due to a cardioprotective effect. Our previous study performed in non-dialysis patients showed that carperitide inhibits POAF, ${ }^{19)}$ and we found that POAF was strongly associated with early death and MACCE in the present study. It is difficult to manage the fluid balance in dialysis patients and POAF can have a considerable influence on survival, so prevention of POAF by carperitide may have reduced the incidence of MACCE. Moreover, it is possible that carperitide reduced postoperative complications due to a protective effect on organs other than the kidney by inhibiting RAAS activation, which is an unwanted effect of cardiopulmonary bypass. While dialysis patients frequently have multiple risk factors and the results of cardiac surgery are not yet satisfactory, the present findings suggest that infusion of carperitide could be useful in their perioperative management. We have previously reported that carperitide is more effective in high-risk patients among patients undergoing cardiac surgery. ${ }^{19)}$ However, the present study was retrospective and further prospective investigation will be required to obtain more evidence.

We found that the mortality rate was low after a single surgical procedure, but the outcome of combined surgery was extremely poor. Previous studies have also revealed poor results in dialysis patients after valve surgery and combined surgery. For example, analysis of 1616 dialysis patients from the Japanese database showed a high operative mortality rate of $13.7 \%{ }^{8)}$ In addition, Thourani et al. reported that the in-hospital mortality rate was $2.9 \%$ after AVR in patients without renal dysfunction, while dialysis patients had a much higher mortality rate of $17.3 \%$, with stroke, infections (mediastinitis and pneumonia), multiple organ failure, and hemorrhage occurring frequently. ${ }^{9)}$ Furthermore, Deutsch et al. studied 204 dialysis patients and reported that the mortality rate was $13.2 \%$ for CABG, $19.3 \%$ for AVR, and $23.8 \%$ for combined procedures, with poor results after valve surgery and combined surgery. ${ }^{11)}$ We confirmed a poor outcome of combined surgery in dialysis patients, with frequent events such as postoperative bleeding, cerebral complications, and infections in the early postoperative period, followed by arrhythmia, sudden death, gastrointestinal bleeding, and infections related to PAD over the long-term. In our previous study, the operative mortality rate of dialysis patients undergoing isolated CABG was $6.9 \%$, while it was $16.7 \%$ for combined surgery and results were poor in the combined group. In addition, all of the operative deaths after isolated CABG were associated with urgent surgery and there were no deaths among patients undergoing elective isolated $\mathrm{CABG}$, but three patients with residual disease who did not receive combined surgery also died eventually. ${ }^{2)}$ Therefore, managing combined surgery will become an issue in the future because more patients will die of residual disease over the long-term if it is not treated surgically. 
The importance of multidisciplinary therapy for improving early postoperative outcomes was demonstrated by this study, and better medium-term results were also achieved. Our findings raised the possibility that perioperative infusion of carperitide can improve outcomes for dialysis patients undergoing cardiac surgery. However, although we demonstrated that carperitide improved the early postoperative outcome and prevented MACCE, we do not have sufficient efficacy data for $\geq 6$ months after surgery. Accordingly, we need to accumulate more patients and evaluate long-term outcomes in the future.

\section{Conclusion}

Our findings in the present study suggest that carperitide improves the early postoperative outcome in dialysis patients undergoing cardiac surgery, as has already been demonstrated in non-dialysis patients. An early postoperative cardioprotective effect of carperitide and improvement of renal function in oliguric patients might be factors contributing to these results. However, this was a retrospective study, so further prospective investigation with longer follow-up will be required to demonstrate the mechanisms involved.

\section{Limitations}

First, this was a retrospective study performed at a single center.

Second, there were more oliguric patients in the carperitide group than the non-carperitide group. Although the difference was not significant, a possible influence on the early and long-term outcomes cannot be excluded. However, our results indicated that carperitide has cardioprotective and organ protective effects, suggesting that a future prospective study is warranted.

\section{Acknowledgments and Funding Sources}

This study was supported by a grant for scientific research from the Japanese Ministry of Education, Culture, Sports, Science and Technology (no. 24592075), Takeda Science Foundation, a Nihon University School of Medicine Alumni 60th Anniversary Medical Research Grant, and a Nihon University School of Medicine Foundation 50th Anniversary Medical Research Grant. These research grants were provided to the lead author, Dr. Akira Sezai.

\section{Disclosure Statement}

Akira Sezai has received lecture fees from Daiichi Sankyo Company. The other authors have no conflicts of interest associated with this study.

\section{References}

1) Kumada $Y$, Ishii $H$, Aoyama $T$, et al. Long-term clinical outcome after surgical or percutaneous coronary revascularization in hemodialysis patients. Circ J 2014; 78: 986-92.

2) Sezai A, Nakata K, Hata M, et al. Long-term results of dialysis patients with chronic kidney disease undergoing coronary artery bypass grafting. Ann Thorac Cardiovasc Surg 2013; 19: 441-8.

3) Takami Y, Tajima K, Kato W, et al. Predictors for early and late outcomes after coronary artery bypass grafting in hemodialysis patients. Ann Thorac Surg 2012; 94: 1940-5.

4) Shroff GR, Li S, Herzog CA. Survival of patients on dialysis having off-pump versus on-pump coronary artery bypass surgery in the United States. J Thorac Cardiovasc Surg 2010; 139: 1333-8.

5) Nakatsu T, Tamura N, Sakakibara Y, et al. Long-term survival after coronary arterial grafts in patients with end-stage renal disease. Ann Thorac Surg 2010; 90: 738-43.

6) Vassileva CM, Brennan JM, Gammie JS, et al. Mitral procedure selection in patients on dialysis: does mitral repair influence outcomes? J Thorac Cardiovasc Surg 2014; 148: 144-50.e1.

7) Fernando M, Paterson HS, Byth K, et al. Outcomes of cardiac surgery in chronic kidney disease. J Thorac Cardiovasc Surg 2014; 148: 2167-73.

8) Takeda K, Miyata H, Motomura N, et al. Contemporary perioperative results of heart valve replacement in dialysis patients: analysis of 1,616 patients from the Japan adult cardiovascular surgery database. J Heart Valve Dis 2013; 22: 850-8.

9) Thourani VH, Keeling WB, Sarin EL, et al. Impact of preoperative renal dysfunction on long-term survival for patients undergoing aortic valve replacement. Ann Thorac Surg 2011; 91: 1798-806; discussion 1806-7.

10) Thourani VH, Sarin EL, Kilgo PD, et al. Short- and longterm outcomes in patients undergoing valve surgery with end-stage renal failure receiving chronic hemodialysis. J Thorac Cardiovasc Surg 2012; 144: 117-23.

11) Deutsch O, Spiliopoulos K, Kiask T, et al. Cardiac surgery in dialysis-dependent patients: impact of gender on early outcome in single-center experience with 204 consecutive cases. Thorac Cardiovasc Surg 2013; 61: $22-8$.

12) Yeo KK, Li Z, Yeun JY, et al. Severity of chronic kidney disease as a risk factor for operative mortality in nonemergent patients in the California coronary artery 
bypass graft surgery outcomes reporting program. Am J Cardiol 2008; 101: 1269-74.

13) Sezai A, Shiono M, Orime Y, et al. Low-dose continuous infusion of human atrial natriuretic peptide during and after cardiac surgery. Ann Thorac Surg 2000; 69: 732-8.

14) Sezai A, Hata M, Niino T, et al. Influence of continuous infusion of low-dose human atrial natriuretic peptide on renal function during cardiac surgery: a randomized controlled study. J Am Coll Cardiol 2009; 54: 1058-64.

15) Sezai A, Hata M, Niino T, et al. Continuous low-dose infusion of human atrial natriuretic peptide in patients with left ventricular dysfunction undergoing coronary artery bypass grafting: the NU-HIT (Nihon University working group study of low-dose Human ANP Infusion Therapy during cardiac surgery) for left ventricular dysfunction. J Am Coll Cardiol 2010; 55: 1844-51.

16) Sezai A, Hata M, Niino T, et al. Results of low-dose human atrial natriuretic peptide infusion in nondialysis patients with chronic kidney disease undergoing coronary artery bypass grafting: the NU-HIT (Nihon University working group study of low-dose HANP Infusion Therapy during cardiac surgery) trial for CKD. J Am Coll Cardiol 2011; 58: 897-903.

17) Sezai A, Nakata K, Iida M, et al. Early results of human atrial natriuretic peptide infusion in non-dialysis patients with chronic kidney disease undergoing isolated coronary artery bypass grafting: the NU-HIT trial for CKD-II. Ann Thorac Cardiovasc Surg 2014; 20: 217-22.

18) Sezai A, Nakata K, Iida M, et al. Results of low-dose carperitide infusion in high-risk patients undergoing coronary artery bypass grafting. Ann Thorac Surg 2013; 96: 119-26.

19) Sezai A, lida M, Yoshitake I, et al. Carperitide and atrial fibrillation after coronary bypass grafting: the Nihon University working group study of low-dose HANP infusion therapy during cardiac surgery trial for postoperative atrial fibrillation. Circ Arrhythm Electrophysiol 2015; 8: 546-53.

20) Valsson F, Ricksten SE, Hedner T, et al. Effects of atrial natriuretic peptide on acute renal impairment in patients with heart failure after cardiac surgery. Intensive Care Med 1996; 22: 230-6.

21) Swärd K, Valsson F, Odencrants P, et al. Recombinant human atrial natriuretic peptide in ischemic acute renal failure: a randomized placebo-controlled trial. Crit Care Med 2004; 32: 1310-5.

22) Park K, Itoh H, Yamahara K, et al. Therapeutic potential of atrial natriuretic peptide administration on peripheral arterial diseases. Endocrinology 2008; 149: 483-91. 